\title{
Phenotypic and Biochemical Characterization of Pectobacterium carotovorum sub sp carotovorum, the Incitant of Onion Soft Rot
}

\author{
V. Sangeetha ${ }^{1}$, S. Harish ${ }^{1 *}$, S. Thiruvudainambi ${ }^{1}$ and A. Beaulah ${ }^{2}$ \\ ${ }^{1}$ Department of Plant Pathology, ${ }^{2}$ Department of Horticulture, Agricultural College and \\ Research Institute, Tamil Nadu Agricultural University, Madurai, Tamil Nadu, India \\ *Corresponding author
}

\begin{tabular}{|l|}
\hline Ke y w o r d s \\
Onion, Soft rot, \\
$\begin{array}{l}\text { Pectobacterium, } \\
\text { Biochemical } \\
\text { characterization }\end{array}$ \\
\hline Article Info \\
\hline $\begin{array}{l}\text { Accepted: } \\
\text { 04 November } 2020 \\
\text { Available Online: } \\
\text { 10 December } 2020\end{array}$ \\
\hline
\end{tabular}

\begin{abstract}
A B S T R A C T
Onion (Allium cepa L.) is one of the most important commercial vegetable crops which have significant nutritional value to the human diet besides possessing medicinal properties. It is affected by various diseases among which soft rot incited by Pectobacterium carotovorum subsp carotovorum (Pcc) is an economically important disease in the field and storage. In the present study, survey carried out in Madurai, Perambalur and Salem districts of Tamil Nadu revealed that the maximum incidence of onion soft rot $(63.25 \%)$ was noticed in Muthampatti of Salem district of Tamil Nadu whereas lowest incidence $(16.39 \%)$ was noticed in Arasakulam of Madurai district. Ten bacterial isolates were isolated from symptomatic onion which produced grey and convex slimy colonies on nutrient agar medium. Biochemical characterization revealed that all the isolates were tested positive for potato soft rot test, catalase production, OF test, gelatin liquefaction, $\mathrm{KOH}$ solubility, methyl red test, and growth in $5 \% \mathrm{NaCl}$ and negative for gram reaction, oxidase and gas formation. In vitro pathogenicity tests showed that, the isolate PCC 6 was found to be high virulent which developed typical water-soaked symptoms in onion bulbs after 2 days and soft rot symptoms were expressed on 4 days after inoculation. The presence of deep pits and cavities zone in agar plates confirmed that all the isolates were Pectobacterium spp. Based on the phenotypic, and biochemical characterization, the isolates were identified as Pectobacterium carotovorum subsp. carotovorum.
\end{abstract}

\section{Introduction}

Onion (Allium cepa) is one of the important food ingredients widely used in our day-today life for culinary purpose (Virginia, 2006). Among the various constraints in onion cultivation, bacterial soft rot caused by Pectobacterium carotovorum subsp. carotovorum is an important disease which causes economical loss to the farmers
(Agrios, 2006). The disease is most common in storage or transit; (Sherf and Macnab, 1986). However, this disease can develop on onions in the field before harvest, after heavy rains and also when the leaves dry (kim et al., 2002). Pectobacterium carotovorum is a species of Gram negative, facultatively anaerobic, rod-shaped bacteria (Whitehead et al., 2002). P. carotovorum subspecies carotovorum is a phytopathogenic 
enterobacterium which is responsible for soft rot, a disease which cause tissue maceration by secreting large amounts of plant cell wall degrading enzymes (PCWDE) which are linked to the type II secretion system (T2SS) (Toth et al., 2003). The disease show characteristic water soaked, slimy rotten appearance of infected plant tissue. A foul smelling viscous fluid oozes from the neck when the infected bulbs are squeezed. In the field, the youngest leaves or the entire leaves of affected plants are bleached and wilted. Characterization and identification of pectolytic erwinia are based on biochemical and phenotypic characteristics (De Boer and Kelman, 2000) and recently molecular techniques have also been applied. $P$. carotovorum subsp. carotovorum has been previously isolated from potato producing areas in Iran (Soltani-Nejad et al., 2005). P. atrosepticum also has been reported in southwest Iran, but the identification was based only on biochemical and physiological characteristics (Kreig et al., 1984). The bacterial isolates originated from single colonies were tested for their ability to cause soft rot on potato tubers following standard procedure (Lelliot et al., 1984).The biochemical or genetic characteristics of $P$. carotovorum strains show diversity among the same subspecies (Nabhan et al., 2006). The aim of the study is to make identification and characterization of the causal agent of bacterial soft rot of onion by using morphological and biochemical methods.

\section{Materials and Methods}

\section{Survey and collection of pathogen}

A survey was conducted in onion growing areas to assess the soft rot disease incidence in Tamil Nadu. Infected onion bulb with soft rot symptoms were collected from the field and market of Madurai, Salem and Perambalur districts of Tamil Nadu. The soft rot disease incidence was assessed by counting the number of affected plants / total number of plants in each plot $\left(25 \mathrm{~m}^{2}\right)$. In each area, three fields were assessed and the mean disease incidence was calculated. The collected samples were used for further studies.

\section{Isolation of soft rot bacteria}

Soft rot bacterial isolates were isolated from different onion samples by "Streak plate" technique as described by Mortensen (1997) and Kim et al., (2002). Nutrient agar (NA) medium was used for the isolation of soft rot bacteria. A small part from the margin of rotted tissues of the infected onion bulbs were removed with a scalpel and were surface disinfected with $70 \%$ ethanol for 2-3 min. Sterilized samples were washed several times in sterilized water to remove the residues. The samples were placed in petridishes containing sterilized water and were crushed with a sterile scalpel. After crushing, the petridishes were kept undisturbed for $10-15 \mathrm{~min}$ to release the bacteria associated with rotted tissues. One loop full of resulting suspension (water containing bacteria) was streaked on the solidified NA medium in each plate. The plates were incubated at $30^{\circ} \mathrm{C}$ for $48 \mathrm{hr}$ (Rahman et al., 2017). Characteristic individual bacterial colonies that appeared on NA medium were picked up using a bacterial loop and transferred to another plate. Purification of bacterial colony was done by re-streaking of single colony on another fresh plate.

\section{Pathogenecity test}

The pathogenecity test was conducted under in vitro conditions in onion bulb. Wounds were made with $0.25 \mathrm{G}$ syringe needle in the onion bulb to inoculate the pathogen. The bacterial inoculum was obtained from 2 days old culture on NA broth incubated at $30^{\circ} \mathrm{C}$ 
and adjusted to $10^{7} \mathrm{Cfu} / \mathrm{ml}$. The bacterial culture@100 $\quad \mu \mathrm{L}$ was inoculated longitudinally from the neck part and transversely from the outer to inner part of the onion bulb. Inoculated onion bulbs were maintained at $30^{\circ} \mathrm{C}$ for 7 day and examined daily for development of symptoms (AbdAlla et al., 2010). Sterile water was used as a negative control. The bacteria from the infected bulbs were re-isolated and the characters were compared with the original isolate and the Koch's postulates were proved.

\section{Biochemical characterization}

A series of biochemical tests were performed for characterization of the isolated pathogen using the protocol already described. The biochemical tests were a. Potato soft rot test b. fermentation of glucose test (OF test) (Hugh and Leifson, 1953), c. Gram reaction (Suslow et al., 1982), d. oxidase reaction (Kavocs, 1956), e. Catalase production (Hayward, 1992), f. Gelatin liquefaction test (Schaad, 1988), g. Urease production (Schaad, 1988), h. Methyl red test, i. Gas formation (Hugh and Leifson, 1953). In crystal violate pectate test, the detection of soft rot erwini as depends on the characteristic deep pits or cavities formed by colonies of the bacteria in Crystal violate pectate medium.

\section{Statistical analysis}

Experimental datas were statistically analyzed using analysis of variance (ANOVA) and the SPSS version 17.0. The treatment means were separated at 5\% significance level using Duncan's Multiple Range Test (DMRT).

\section{Results and Discussion}

\section{Survey and isolation of pathogen}

A survey carried out in Madurai, Perambalur and Salem districts of Tamil Nadu revealed that the maximum incidence of onion soft rot $(63.25 \%)$ was noticed in Muthampatti of Salem district of Tamil Nadu whereas lowest incidence $(16.39 \%)$ was noticed in Arasakulam of Madurai district.

Ten isolates of Pectobacterium carotovorum subsp carotovorum was isolated from infected onion from various field and market regions. The isolates produced creamy white slimy colonies in nutrient agar which was maintained in pure culture for further studies (Table $1 \& 2$ ).

\section{Pathogenecity test}

All the isolates recovered from diseased onion were individually inoculated into healthy onion in vitro by wound inoculation method. Among these ten isolates, PCC 6 was found to be high virulent and PCC 1 was found to be least virulent.

The isolate produced water soaked lesion in onion 2 days after inoculation and typical soft rot symptoms appeared after 4 days (Fig 1a and $1 b)$.

Biochemical characterization of the pathogen

The results of the biochemical characterization revealed that all the isolates were tested positive for potato soft rot test, catalase production, OF test, gelatin liquefaction, $\mathrm{KOH}$ solubility, methyl red test, and Growth in 5\% $\mathrm{NaCl}$ and negative for gram reaction, oxidase and gas formation (Table 3).

\section{Crystal violate pectate test}

All the isolates produced deep pits and cavities zone in crystal violet pectate (CVP) medium which confirmed the isolates as Pectobacterium sp. (Fig. 2). 
Table.1 Origin and collection of isolates used in this study

\begin{tabular}{|c|c|c|c|c|c|c|}
\hline S.No & Place of collection & Districts & Isolate name & \multicolumn{2}{|c|}{ Geo co-ordinates } & \multicolumn{2}{|c|}{$\begin{array}{c}\text { Percent disease } \\
\text { incidence }(\mathbf{\%})^{*}\end{array}$} \\
\hline & & & & Latitude & Longitude & \\
\hline $\mathbf{1}$ & Arasakulam & Madurai & PCC1 & $9.79 \mathrm{~N}$ & $78.79 \mathrm{E}$ & 16.39 \\
\hline $\mathbf{2}$ & Aaviyur & Madurai & PCC2 & $9.98 \mathrm{~N}$ & $78.11 \mathrm{E}$ & 23.96 \\
\hline $\mathbf{3}$ & Anukkur & Perambalur & PCC3 & $11.66 \mathrm{~N}$ & $78.48 \mathrm{E}$ & 21.68 \\
\hline $\mathbf{4}$ & Keelaperambalur & Perambalur & PCC4 & $11.08 \mathrm{~N}$ & $79.57 \mathrm{E}$ & 20.29 \\
\hline $\mathbf{5}$ & Valappady & Salem & PCC5 & $11.03 \mathrm{~N}$ & $78.03 \mathrm{E}$ & 21.55 \\
\hline $\mathbf{6}$ & Muthampatti & Salem & PCC6 & $11.25 \mathrm{~N}$ & $78.11 \mathrm{E}$ & 63.25 \\
\hline $\mathbf{7}$ & Thukkiyampalayam & Salem & PCC7 & $11.22 \mathrm{~N}$ & $78.04 \mathrm{E}$ & 25.41 \\
\hline $\mathbf{8}$ & Othakadai (Market) & Madurai & PCC8 & $9.35 \mathrm{~N}$ & $78.16 \mathrm{E}$ & 26.26 \\
\hline $\mathbf{9}$ & Simakkal (Market) & Madurai & PCC9 & $9.36 \mathrm{~N}$ & $78.19 \mathrm{E}$ & 30.56 \\
\hline $\mathbf{1 0}$ & Maatuthavani (Market) & Madurai & PCC10 & $9.48 \mathrm{~N}$ & $78.84 \mathrm{E}$ & 17.97 \\
\hline $\mathbf{C D}$ (p=0.05) & & & & & 0.84 \\
\hline
\end{tabular}

*Mean of three replications

Table.2 Cultural characters of different isolates of Pectobacterium carotovorum subsp carotovorum

\begin{tabular}{|l|l|l|}
\hline Isolate & Colony colour & Appearance \\
\hline PCC1 & Creamy white & Slimy \\
\hline PCC2 & Grayish white & Slimy \\
\hline PCC3 & Creamy white & Slimy \\
\hline PCC4 & white & Slimy \\
\hline PCC5 & Creamy white & Slimy \\
\hline PCC6 & Creamy white & Slimy \\
\hline PCC7 & Creamy white & Slimy \\
\hline PCC8 & Creamy white & Slimy \\
\hline PCC9 & Grayish creamy white & Slimy \\
\hline PCC10 & Grayish creamy white & Slimy \\
\hline
\end{tabular}

Table.3 Biochemical characteristics of soft rot bacteria isolated from Onion

\begin{tabular}{|c|c|c|c|c|c|c|c|c|c|c|}
\hline \multirow[t]{2}{*}{ Isolates } & \multicolumn{10}{|c|}{ Biochemical test } \\
\hline & $\begin{array}{l}\text { Gram } \\
\text { reaction }\end{array}$ & $\begin{array}{l}\text { Potato } \\
\text { soft rot }\end{array}$ & $\begin{array}{l}\text { Catal } \\
\text { ase }\end{array}$ & Oxidase & $\begin{array}{l}\text { OF } \\
\text { test }\end{array}$ & $\begin{array}{l}\text { Gelatin } \\
\text { liquefaction }\end{array}$ & $\begin{array}{l}\mathrm{KOH} \\
\text { solubility }\end{array}$ & $\begin{array}{l}\text { Methyl } \\
\text { red test }\end{array}$ & $\begin{array}{l}\text { Gas } \\
\text { formation }\end{array}$ & $\begin{array}{l}\text { Growth in } \\
5 \% \mathrm{Nacl}\end{array}$ \\
\hline PCC1 & - & + & + & - & + & + & + & + & - & + \\
\hline PCC2 & - & + & + & - & + & + & + & + & - & + \\
\hline PCC3 & - & + & + & - & + & + & + & + & - & + \\
\hline PCC4 & - & + & + & - & + & + & + & + & - & + \\
\hline PCC5 & - & + & + & - & + & + & + & + & - & + \\
\hline PCC6 & - & + & + & - & + & + & + & + & - & + \\
\hline PCC7 & - & + & + & - & + & + & + & + & - & + \\
\hline PCC8 & - & + & + & - & + & + & + & + & - & + \\
\hline PCC9 & - & + & + & - & + & + & + & + & - & + \\
\hline PCC10 & - & + & + & - & + & + & + & + & - & + \\
\hline
\end{tabular}


Fig.1a Pathogenicity of Pectobacterium spp. in Onion

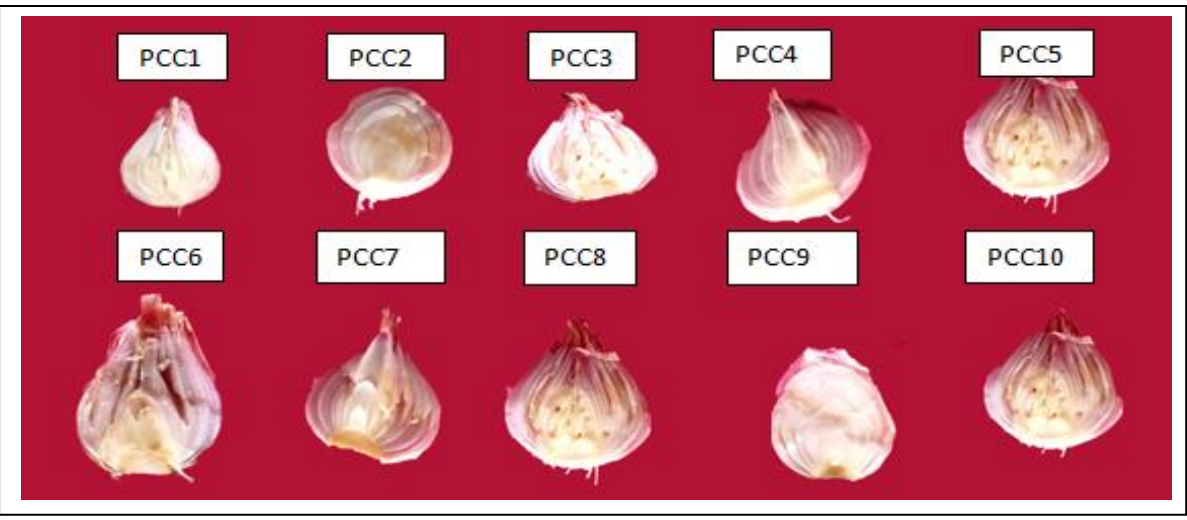

Fig.1b Pathogenicity test of different isolates of onion soft rot

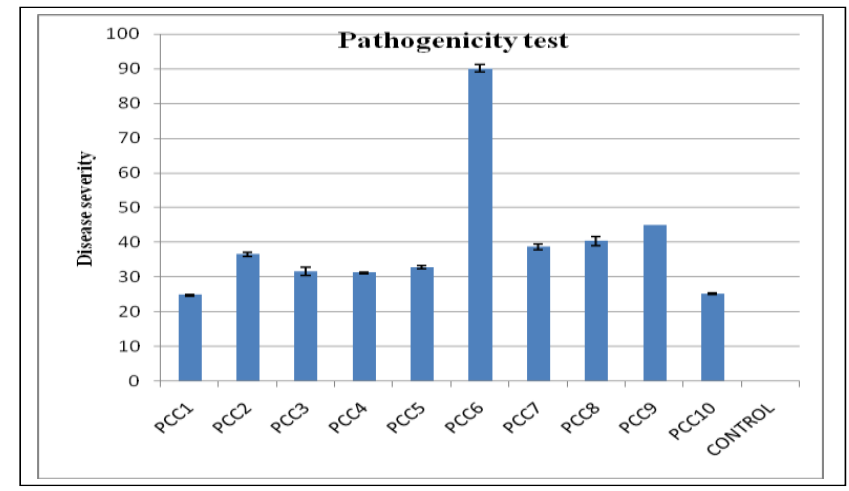

Fig.2 Crystal violet pectate test

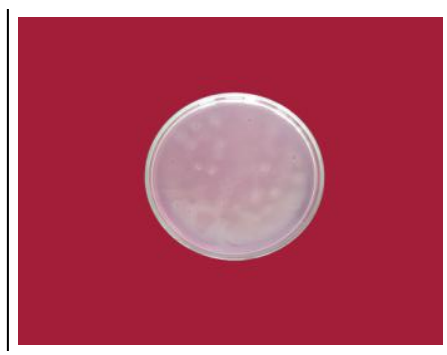

In this study, pectolytic bacterial isolates from onion was identified using a combination of phenotypic and biochemical tests. The results are in accordance with Toth et al., 1999; Ma et al., 2007; Baghaee-Ravari et al., 2011. Characterization and identification of pectolytic erwinias are traditionally based on biochemical and phenotypic characteristics and more recently molecular techniques have also been applied by De Boer and Kelman (2000). The most commonly used methods are biochemical tests (Dickey and Kelman, 1988) and pathogenicity tests (Smith and Bartz, 1990). Pectobacterium form deep cavities in CVP medium which is a very useful to confirm the pathogen as Pectobacterium spp. CVP medium and bioassays on Onion used for pectinolytic 
strains selection, connected with use of the genus specific primers Y1/ Y2 (Darrasse et al., 1994), proved to be very useful, cheap and efficient method for identification of Pectobacterium spp., (Nazerian et al., 2013). Erwinia carotovora subspecies atroseptica has been recorded as soft rot pathogen for few vegetables which is restricted to the cool and temperate regions and has a host range limited almost exclusively to potato (Fahy and Persley, 1983, Toth et al., 2003). so this is from the few reports of bacterial rot of onion caused by Erwinia carotovora subspecies atroseptica. Hence, in this study, survey, collection, isolation and characterization of onion bacterial soft rot was done. The pathogen was isolated from onion bulb showing soft rot symptom and incubated. The identification of the pathogen in our present study based on phenotypic and biochemical characters. All of the bacterial isolates originated from single colonies were tested for their ability to cause soft rot on onion bulbs following standard procedure (Gore et al., 2020). According to the research conducted by Sendhilvel et al., (2005), the colonies were greyish white, smooth, round, occur singly and occasionally in short chain. Better growth of the bacterium was observed at $37^{\circ} \mathrm{C}$. The isolate of Pectobacterium carotovora subsp. carotovora showed negative reaction towards gram reaction and oxidase test and gas formation which is in accordance with (Gore et al., 2020) where as it shows positive reaction towards $\mathrm{KOH}$ test, catalase test, potato soft rot test, gelatin liquification test, growth in 5\% Nacl test, $\mathrm{H} 2 \mathrm{~S}$ production test, indole production test, $\mathrm{OF}$ test and methyl red test. We conclude that the isolated bacterium in the ooze was identified as Pectobacterium carotovorum subsp. carotovorum and its pathogenicity was established. Thus, from the confirmation of the pathogen, it can be utilized for evaluating the best biocontrol agents for management of this disease.

\section{References}

Abd-Alla MH, Bashandy SR, Schnell S. 2010. Occurrence of Xanthomonas axonopodis pv. Phaseoli, the causal agent of common bacterial blight disease, on seeds of common bean (Phaseolus vulgaris L) in Upper Egypt. Folia Microbiol. 55, 47-52.

Agrios G.N, 2006. "Contol of plant diseases," in Plant pathology, $5^{\text {th }}$ Ed., Academic press, San Diego, Calif, USA. 200-216.

Baghaee-Ravari, S., Rahimian, H., Shamsbakhsh, M., Lopez- solanilla, E., Antunez- Lamas, M., and Rhodrigeuzpalenzuela, P. 2011. Characterization of Pectobacterium species from Iran using biochemical and molecular methods. European Journal of Plant Pathology, 129, 413-425.

Darrasse A., Priou S., Kotoujansky A., Bertheau Y., 1994. PCR and restriction fragment length Polymorphism of pel gene as a tool to identify Erwinia carotovora in relation to potato Diseases. Applied Environmental Microbiology 60: 1437-1443.

De Boer SH and Kelman A. 2000. Gramnegative bacteria: Erwinia soft rot group In: Laboratory Guide for Identification of Plant Pathogenic Bacteria, Eds. Schaad NW, Jones JB and Chun W, 3rd Ed., pp. 56-72.

Dickey RS and Kelman A. 1988.Erwinia carotovora or soft rot group In: Schaad NW Laboratory Guide for Identification of Plant Pathogenic Bacteria, 2nd Ed., St Paul. MN, American Phytopathological Society, p 44- 59.

Fahy P, Parsley G (1983). Plant Bacterial Diseases. (1st ed.), Sydney: Academic Press.

Gore PM, Ingle RW and Rakhonde PN. 2020. Management of bulb rot of onion caused by Erwinia carotovora pv. Carotovora, Journal of Pharmacognosy and 
Phytochemistry, 2020; 9(4): 3294-3301

Hayward AC. 1992. Identification of Pseudomonas solanacearum. In: SAVERNET Bacterial Wilt Training Course held on October 5 to November 16 AVRDC, $p 101$.

Hugh R and Leifson E. 1953. The taxonomic significance of fermentative versus oxidative metabolism of carbohydrates by various gram-negative bacteria, J. Bacteriol 66: 24-26.

Kovacs N. 1956. Identification of Pseudomonas solanacearum by the oxidase reaction, Nature, 178: 703.

Kreig NR and Holt JG. 1984. Bergey's manual of systematic bacteriology, Vol. I, Williams and Wilkins, London, pp. 141-177.

Lelliot RA and Dickey RS. 1984. Genus VII. Erwinia Winslow, Broadhurst, Buchanan, Krumwiede, Rogers and Smith 1920, 209AL In: Bergey's Manual of Systematic Bacteriology, Vol. 1, Eds. Krieg NR and Holt JG, Williams \& Wilkins Co, Baltimore, pp 469-476.

Ma B., Hibbing M.E., Kim H.S., Reedy R.M., Yedidia I., Breuer J., Glasner J.D., Perna N.T., Kelman A., Charkowski A.O., 2007. Host range and molecular phylogenies of the soft rot enterobacterial genera Pectobacterium and Dickeya. Phytopathology 97: 11501163.

Mortensen CN. 1997. Seed Bacteriology laboratory guide, Danish Govt. Ins. Seed Pathol (DGISP) for developing countries, Copenhagen, Denmark, pp 12.

Nabhan S, Al-Chaabi S and Abu-Ghorrah M. 2006. Evaluation of pathogenicity of different Erwinia isolates causal agents of potato soft rot and blackleg, and assessment of susceptibility of some potato cultivars under laboratory conditions, 9th Arab Congress of Plant Protection, 19-23 November 2006,
Damascus, Syria.

Nazerian E., Sijam K., Ahmad Z.A.M., Vadamalai G., 2013. Characterization of Pectobacterium Carotovorum subsp. carotovorum as a new disease on Lettuce in Malaysia. Australasian Plant Disease Notes 8: 105-107.

Rahman M.M, Khan M.A.A, Mian I.H, Akanda A.M and Alam M.Z. 2017. Characterization of Onion soft rot bacteria in Bangladesh, Bangladesh J. Sci. Ind. Res. 52(3), 209-220.

Schaad NW. 1988. Laboratory guide for identification of plant pathogenic bacteria, Bacteriol. Commit. Amr. Phytopath. Soc. Minesota.

Sendhilvel V, Marimuthu T, Raguchander T and Prabakar K. 2005. Biochemical methods for the detection of Erwinia carotovora var carotovora from Onion seeds, Madras Agric. J. 92(4-6): 234237.

Sherf AF and Macnab AA. 1986. Vegetable diseases and their control, 2nd Ed., A Wiley I Interscience Publication, John Wiley and Sons, Inc. New York. Kim YK, Lee SD, Choi Lee SB and Lee SY. 2002. Soft rot of Onion bulbs caused by Pseudomonas marginalis Under low temperature storage, The Korean Society of Plant Pathology, Plant Pathol. J. 18(4): 199-203.

Smith C and Bartz JA (1990), Variation in the pathogenicity and aggressiveness of isolates of Erwinia carotovora subsp. carotovora isolated from different hosts, Plant Dis. 74: 505- 509.

Soltani Nejad S, Taghavi M, Hayati J, Mostofi Zadeh R. 2005. Study of phenotypic and Pathogenicity characteristics of Pectobacterium causing soft rot in Khozestan province. Iran J Plant Pathol 41:585-611.

Suslow TV, Schroth MN and Isaka M. 1982. Application of a rapid method for Gramdifferentiation of plant pathogenic 
and saprophytic bacteria without staining, Phytopathol 72: 917-98.

Toth I.K., Bertheau Y., Hyman L.J., Laplaze L., Lopez M.M., McNicol J., Niepold F., Persson P., Salmond G.P.C., van der Wolf J.M., Perombelon M.C., 1999. Evaluation of phenotypic and molecular typing techniques for determining diversity in Erwinia carotovora subsp. atroseptica. Journal of Applied Microbiology 87: 770-781.

Toth IK, Bell KS, Holeva MC, Birch PRJ. 2003. Soft rot erwiniae: from genes to genomes. Mol Plant Pathol 4:17-30.

Toth, I. K., Sullivan, L., Brierley, J. L., Avrova, A. O., Hyman, L. J., Holeva, M., Boadfoot, L., P Perombelon, M. V. M., and McNicol, J. 2003. Relationship between poato seed tuber comtamination by Erwinia Carotovora ssp. Atroseptica, black leg disease development and progeny tuber contamination. Plant Pathology, 52, 119-126.

Virginia Lanzotti. 2006. "The analysis of Onion and Garlic". Journal of chromatography 1112 (1- 2), 3-22.

Whitehead NA, Byers JT, Commander P, Corbett MJ, Coulthurst SJ, Everson L, Harris AK, Pemberton CL, Simpson NJ, Slater H, Smith DS, Welch M, Williamson N, Salmond GP. 2002. The regulation of virulence in phytopathogenic Erwinia species: quorum sensing, antibiotics and ecological considerations. Antonie Van Leeuwenhoek, 81, 223-231.

\section{How to cite this article:}

Sangeetha, V., S. Harish, S. Thiruvudainambi and Beaulah, A. 2020. Phenotypic and Biochemical Characterization of Pectobacterium carotovorum sub sp carotovorum, the Incitant of Onion Soft Rot. Int.J.Curr.Microbiol.App.Sci. 9(12): 8-15. doi: https://doi.org/10.20546/ijcmas.2020.912.002 